\title{
Pengaruh Model Pembelajaran Kooperatif Tipe Make A Match Berbantuan Media Powerpoint Terhadap Hasil Belajar IPA
}

\author{
${ }^{*}$ Pt. Anggreni Astawa ${ }^{1}$, I Md. Tegeh ${ }^{2}$
}

1 Jurusan Pendidikan Guru Sekolah dasar, Fakultas Ilmu Pendidikan Universitas Pendidikan Ganesha, Indonesia

2Jurusan Teknologi Pendidikan Fakultas Ilmu Pendidikan Universitas Pendidikan Ganesha, Indonesia

\author{
A R T I C L E I N F O \\ Article history: \\ Received 10 November \\ 2018 \\ Received in revised form \\ 09 December 2018 \\ Accepted 15 January 2019 \\ Available online 25 \\ February 2019 \\ Kata Kunci: \\ make a match, powerpoint. \\ IPA \\ Keywords: \\ make a match, powerpoint, \\ IPA
}

\begin{abstract}
A B S T R A K
Rendahnya hasil belajar IPA denggan model pembelajaran konvensional. Penelitian ini bertujuan untuk mengetahui perbedaan yang signifikan hasil belajar IPA antara siswa yang mengikuti model pembelajaran kooperatif tipe make a match berbantuan media PowerPoint dan siswa yang mengikuti pembelajaran konvensional pada kelas III SD. Jenis penelitian ini adalah penelitian eksperimen semu dengan rancangan non equivalent post-test only control group design. Populasi penelitian ini adalah seluruh siswa kelas III SD yang berjumlah 235 orang siswa. Teknik yang digunakan untuk menentukan sampel adalah cluster random sampling. Sampel penelitian ini adalah kelas III B di SD yang berjumlah 33 orang siswa sebagai kelompok eksperimen dan kelas III di SD yang berjumlah 33 orang siswa sebagai kelompok kontrol. Data hasil belajar IPA dikumpulkan dengan intrumen tes berupa soal pilihan ganda. Data yang diperoleh dianalisis dengan menggunakan analisis statistik deskriptif dan statistik inferensial yaitu
\end{abstract} uji-t. Rata-rata skor siswa kelompok eksperimen lebih tinggi dibandingkan dengan rata-rata skor siswa kelompok kontrol. Hasil penelitian menunjukkan bahwa terdapat perbedaan yang signifikan hasil belajar IPA antara siswa yang mengikuti model pembelajaran kooperatif tipe make a match berbantuan media PowerPoint dan siswa yang mengikuti pembelajaran konvensional. Dengan demikian, model pembelajaran kooperatif tipe make a match berbantuan media PowerPoint berpengaruh terhadap hasil belajar IPA siswa kelas III SD.

\begin{abstract}
A B S T R A C T
The research aimed to determine the significant difference of natural science learning achievement between grade III students who learned natural science with cooperative learning model type make a match supported by PowerPoint and the students who learned natural science with conventional learning. This was a quasi experimental research with non equivalent post-test only control group design. The population of this research was all of the third grade of elementary school students cluster VIII in Mengwi subdistrict with 235 students in total. The sampling technique in this research was cluster random sampling. The samples of this research were the third grade students in SD which consisted of 33 students as the experiment group and the third grade students in SD which consisted of 33 students as the control group. The data were collected using multiple choice test and analyzed by descriptive statistic and statistic inferential through $t$-test. The average score of experiment group students is higher than the average score of control group students. The result of this research shows that there is significant difference of natural science learning achievement between grade III students who learned natural science with cooperative learning model type make a match supported by PowerPoint and the students who learned natural science with conventional learning. Therefore, cooperative learning model type make a match supported by PowerPoint has an effect towards the natural science learning achievement of third grade elementary school students cluster subdistrict in the academic year of 2017/2018.
\end{abstract}

Copyright (c) Universitas Pendidikan Ganesha. All rights reserved. 


\section{Pendahuluan}

Siswa adalah sumber daya manusia yang memiliki banyak potensi dan kemampuan yang perlu dibina dan dikembangkan. Potensi dan kemampuan tersebut akan berkembang secara optimal melalui pendidikan. Hal ini sesuai dengan tujuan pendidikan nasional seperti yang disebutkan dalam UndangUndang Nomor 20 Tahun 2003 tentang Sistem Pendidikan Nasional (SISDIKNAS) Bab II Pasal 3 yaitu tujuan pendidikan nasional adalah untuk mengembangkan kemampuan dan membentuk watak serta peradaban bangsa yang bermartabat dalam rangka mencerdaskan kehidupan bangsa, yang bertujuan untuk berkembangnya potensi peserta didik agar menjadi manusia yang beriman dan bertaqwa kepada Tuhan Yang Maha Esa, berakhlak mulia, sehat, berilmu, cakap, kreatif, mandiri dan menjadi warga negara yang demokratis serta bertanggung jawab(Kemendikbud, 2003).Adanya luapan perkembangan ilmu pengetahuan dan teknologi di masyarakat, mewujudkan tujuan pendidikan yang sedemikian rupa membawa konsekuensi serta persyaratan yang semakin kompleks bagi pelaksana dalam sektor pendidikan, khususnya bagi guru. Guru harus meningkatkan kualitas serta cara mengajarnya sehingga mampu menciptakan suasana belajar yang menyenangkan yang akan membuat pembelajaran menjadi optimal. Proses pembelajaran yang baik akan menciptakan pendidikan yang bermutu yang mampu mencetak sumber daya manusia yang berkualitas(Rusman, 2017).

Untuk mewujudkan proses pembelajaran yang baik, seorang guru diharapkan mampu menjadi pendidik yang profesional. Salah satu kompetensi yang dimiliki oleh guru profesional adalah pedagogik dimana guru dituntut untuk menerapkan berbagai model, pendekatan, strategi, teknik. dan metode pembelajaran yang mendidik secara kreatif dalam seluruh mata pelajaran. Guru profesional seperti ini diperlukan pada semua jenjang pendidikan termasuk jenjang pendidikan sekolah dasar. Sekolah dasar (SD) merupakan jenjang pendidikan yang paling dasar dan awal dari tertanamnya pendidikan formal. Pesatnya kemajuan ilmu pengetahuan dan teknologi menuntut siswa SD mengembangkan kemampuannya dalam beberapa bidang akademis, salah satunya yaitu Ilmu Pengetahuan Alam (IPA). IPA merupakan salah satu bidang akademis yang dianggap memiliki peran vital bagi perkembangan mental dan pola pikir siswa SD kedepannya. Utari, Degeng, \& Akbar (2016) menyatakan bahwa pendidikan di sekolah dasar bertujuan untuk mengembangkan sikap dan kemampuan serta memberikan pengetahuan dan keterampilan dasar yang diperlukan untuk hidup dalam masyarakat. Salah satu disiplin ilu yang dapat mencapai tujuan tersebut adalah IPA.

Pelajaran IPA dianggap begitu penting diajarkan di jenjang sekolah dasar karena mengandung nilainilai yang dibutuhkan oleh siswa untuk terjun ke masyarakat nantinya. Pendidikan IPA di SD bertujuan agar siswa mempunyai pengetahuan, gagasan dan konsep yang terorganisir tentang alam sekitar, yang diperoleh dari pengalaman melalui serangkaian proses ilmiah seperti penyelidikan, penyusunan, dan penyajian gagasan. Mengingat pentingnya pembelajaran IPA pada jenjang sekolah dasar, guru harus mampu mengemas pembelajaran menjadi menyenangkan dan bermakna bagi siswa. Salah satu cara yang dapat dilakukan yaitu dengan menerapkan model-model pembelajaran yang inovatif. Penggunaan model pembelajaran yang tepat mampu meningkatkan hasil dan partisipasi siswa dalam proses pembelajaran. Siswa akan menjadi lebih aktif sehingga pembelajaran dapat berlangsung secara efektif yang akan berakibat pada peningkatan hasil belajar siswa.

Namun pada kenyataannya, nampaknya pembelajaran seperti itu sulit terwujud. Pembelajaran IPA di kelas III SD di Gugus VIII Kecamatan Mengwi belum berjalan dengan optimal. Seperti saat melaksanakan pencatatan data dan observasi pada kelas III SD di Gugus VIII Kecamatan Mengwi yang didampingi oleh para wali kelas, ditemukan bahwa hasil belajar siswa kelas III pada mata pelajaran IPA masih sangat rendah. Hal ini dibuktikan dari hasil UTS IPA siswa dimana masih banyak siswa yang tidak mencapai KKM. Adapun penyebab rendahnya hasil belajar IPA yaitu proses pembelajaran yang masih berpusat pada guru, kurangnya inovasi guru dalam mengelola proses pembelajaran seperti penggunaan model pembelajaran yang inovatif dalam pelaksanaan pembelajaran IPA di kelas, serta kurangnya penggunaan media pembelajaran. Hal-hal tersebut menjadikan pembelajaran kurang menarik perhatian siswa yang pada akhirnya berdampak pada rendahnya hasil belajar IPA siswa.

Terkait dengan pemasalahan tersebut, pembaharuan terhadap pola pembelajaran IPA di kelas sangatlah diperlukan. Maka perlu diterapkannya suatu model pembelajaran yang mampu menjadikan pembelajaran bermakna dan menyenangkan. Model pembelajaran yang dimaksud adalah model pembelajaran kooperatif tipe make a match. Model pembelajaran make a match ini dikembangkan oleh Loma Curran dan merupakan bagian dari salah satu model pembelajaran kooperatif. Model pembelajaran kooperatif tipe make a match akan menjadikan siswa aktif dalam pembelajaran karena siswa harus bekerja sama dengan siswa lainnya agar dapat menemukan pasangan dari kartu yang berisi pertanyaan atau jawaban yang telah mereka dapatkan masing-masing mengenai suatu konsep atau topik. model pembelajaran kooperatif tipe Make A Match bertujuan untuk menumbuhkan sikap saling menghormati, 
menumbuhkan sikap tanggung jawab, meningkatkan percaya diri dalam menyelesaikan suatu masalah (Hazillia, 2018). Salah satu faktor yang mempengaruhi hasil belajar siswa adalah penggunaan model atau metode pembelajaran yang tepat. Kooperatif tipe Make A Match merupakan salah satu model pembelajaran yang digunakan untuk dapat meningkatkan hasil belajar siswa. Model pembelajaran ini dapat digunakan oleh para guru sebagai dasar melaksanakan kegiatan pembelajaran dengan baik, dan sebagai suatu alternatif dalam usaha meningkatkan hasil belajar siswa (Tangkas, 2014).

Model pembelajaran Make A Match atau mencari pasangan dikembangkan pertama kali pada 1994 oleh Lorna Curran (Kurniasih \& Sari, 2015). Menurut Febriyani S, Sri Mulyani dan Suryadi Budi Utomo (2014) dalam jurnalnya menyatakan bahwa pembelajaran kooperatif tipe Make A Match merupakan pembelajaran dengan membagi peserta didik ke dalam kelompok kecil dan mencari pasangan. Pembelajaran ini termasuk pembelajaran aktif dan merupakan salah satu teknik instruksional dari berpikir 4 aktif yang dapat membantu peserta didik dalam hal mengingat apa yang telah mereka pelajari dan dapat menguji pemahaman peserta didik stelah guru menjelaskan materi pembelajaran (Rofiana, 2017). Model pembelajaran kooperatif teknik make a match siswa akan lebih bersemangat karena model pembelajaran tersebut terdapat unsur permainannya, selain itu siswa pun dilibatkan langsung dalam pembelajaran. Teknik make a match ini mampu menciptakan kondisi kelas yang interaktif, efektif sebagai sarana untuk melatih keberanian siswa, serta mampu menghilangkan kebosanan siswa ketika pembelajaran berlangsung(Wirayana, 2017).

Shoimin (2014) menyatakan bahwa model pembelajaran make a match memiliki hubungan yang erat dengan karakteristik siswa yang gemar bermain. Pelaksanaan model make a match harus didukung dengan keaktifan siswa untuk bergerak mencari pasangan dengan kartu sesuai jawaban atau pertanyaan dalam kartu tersebut. Dalam pembelajaran model make a match, suasana belajar di kelas diciptakan sebagai suasana permainan karena adanya kompetisi di antara siswa untuk memecahkan masalah terkait dengan materi pelajaran dan adanya penghargaan. Adanya unsur permainan dalam suatu proses pembelajaran akan menjadikan pembelajaran menjadi lebih menarik dan menyenangkan. Dengan demikian, guru dapat menerapkan model pembelajaran kooperatif tipe make a match ini pada pembelajaran IPA agar pembelajaran menjadi menarik dan menyenangkan sehingga siswa tertarik dan lebih aktif dalam mengikuti kegiatan pembelajaran.

Untuk menjadikan pembelajaran semakin menarik perhatian siswa, maka dalam penerapan model pembelajaran kooperatif tipe make a match ini perlu dilengkapi dengan sebuah media pembelajaran. Media pembelajaran yang digunakan yaitu Microsoft PowerPoint yang akan berperan penting dalam penyampaian materi pembelajaran sebelum dimulainya kegiatan mencari pasangan kartu (make a match). PowerPoint memiliki kemampuan yang sangat baik dalam menyajikan sebuah materi presentasi karena dapat mengolah teks, gambar, warna, tampilan, dan animasi-animasi yang dapat disesuaikan dengan kebutuhan siswa.Menurut pendapat Giri (2017), kelebihan PowerPoint yaitu dapat membuat penyampaian materi pembelajaran menjadi semakin menarik dan dapat diingat baik oleh siswa karena di dalamnya dapat disertai dengan gambar-gambar serta animasi.

Media PowerPoint merupakan pilihan tepat mengingat pelajaran IPA sangat lekat dengan gambargambar serta video sehingga dengan menggunakan PowerPoint, siswa mampu memahami materi yang sedang dibahas dengan jelas. Oleh karena itu, penggunaan PowerPoint sebagai media akan membuat siswa lebih tertarik untuk mengikuti pembelajaran sehingga mereka mampu memahami materi yang diajarkan dengan lebih mudah serta diharapkan mampu meningkatkan hasil belajar IPA siswa itu sendiri. Berdasarkan pemaparan di atas, dapat ditarik pemahaman bahwa kemungkinan besar penerapan model pembelajaran kooperatif tipe make a match berbantuan media PowerPoint dapat memengaruhi hasil belajar IPA siswa. Oleh karena itu, peneliti tertarik untuk melaksanakan penelitian yang berjudul "Pengaruh Model Pembelajaran Kooperatif Tipe Make A Match Berbantuan Media PowerPoint Terhadap Hasil Belajar IPA Siswa Kelas III SD di Gugus VIII Kecamatan Mengwi Tahun Pelajaran 2017/2018".

Tujuan yang ingin dicapai dalam penelitian ini adalah untuk mengetahui perbedaan yang signifikan hasil belajar IPA antara siswa kelas III yang mengikuti model pembelajaran kooperatif tipe make a match berbantuan media PowerPoint dan siswa yang mengikuti pembelajaran konvensional pada kelas III SD di Gugus VIII Kecamatan Mengwi tahun pelajaran 2017/2018.

\section{Metode}

Penelitian dilaksanakan di SD Gugus VIII Kecamatan Mengwi, Kabupaten Badung Tahun Pelajaran 2017/2018 yang dimulai dari 2 April sampai tanggal 27 April 2017. Penelitian ini tergolong eksperimen semu (quasi experiment) karena tidak semua variabel yang muncul dapat diatur dan dikontrol secara ketat. Rancangan yang digunakan adalah non equivalent post-test only control group design. 
Tabel 1. Non Equivalent Post-Test Only Control Group Design

\begin{tabular}{ccc}
\hline Kelas & Treatment & Post-test \\
\hline $\mathrm{E}$ & $\mathrm{X}_{1}$ & 01 \\
\hline $\mathrm{K}$ & - & 02 \\
\hline
\end{tabular}

(Dimodifikasi dari Gall, et al., dalam Agung, 2014:163)

Keterangan:

E : Kelompok Eksperimen

$\mathrm{K} \quad$ : Kelompok Kontrol

$\mathrm{X}_{1} \quad$ : Perlakuan menggunakan model pembelajaran kooperatif tipe make a match berbantuan media PowerPoint.

$\mathrm{O}_{1} \quad$ : Posttest untuk kelompok eksperimen setelah perlakuan

$\mathrm{O}_{2} \quad$ : Posttest untuk kelompok kontrol setelah perlakuan.

- $\quad$ : Pembelajaran konvensional

Dari rancangan penelitian di atas dapat dijelaskan bahwa dalam penelitian ini terdapat dua kelompok yaitu kelompok eksperimen dan kelompok kontrol. Kelompok eksperimen diberikan perlakuan model pembelajaran kooperatif tipe make a match berbantuan media PowerPoint, sedangkan kelompok kontrol menggunakan pembelajaran seperti biasa (pembelajaran konvensional). Kemudian, kedua kelompok ini dikenai pengukuran yang sama. Populasi dalam penelitian ini adalah semua siswa kelas III SD di Gugus VIII Kecamatan Mengwi yang terdiri dari tujuh sekolah dasar. Adapun jumlah seluruh populasi adalah 235 siswa. Dalam pemilihan sampel untuk kelompok kontrol dan kelompok eksperimen, digunakan teknik cluster random sampling yaitu dengan cara undian. Pada teknik cluster random sampling ini subjek-subjek di dalam populasi dianggap sama dan mendapat hak yang sama untuk memperoleh kesempatan dipilih menjadi anggota sampel(Agung, 2014).

Cara yang digunakan menentukan sampel adalah masing-masing kelas III tiap sekolah diberikan nomor urut. Karena dari hasil uji kesetaraan semua kelas III di Gugus VIII memiliki kemampuan yang setara, maka dilanjutkan dengan memilih dua kelas secara random untuk dijadikan sampel. Berdasarkan hasil pengundian, maka diperoleh sampel yaitu kelas III B SD No. 3 Mengwi sebagai kelompok eksperimen dan kelas III SD No. 1 Mengwi sebagai kelompok kontrol. Kelompok eksperimen diberikan perlakuan dengan menggunakan model pembelajaran kooperatif tipe make a match berbantuan media PowerPoint, sedangkan kelompok kontrol tetap menggunakan pembelajaran seperti biasa (pembelajaran konvensional).Data yang dikaji dalam penelitian ini adalah hasil belajar IPA. Pengumpulan data dalam penelitian ini dilakukan dengan metode tes. Dalam penelitian ini, hasil belajar yang diukur hanya pada aspek kognitif saja, maka hasil belajar IPA siswa akan diukur dengan cara memberikan tes pilihan ganda yang berjumlah 30 butir soal. Instrumen tes ini disusun berdasarkan kisi-kisi tes yang berpedoman pada kurikulum yang digunakan, Standar Kompetensi, Kompetensi Dasar, dan juga penyusunannya didasarkan pada domain kognitif Taksonomi Bloom Revisi Anderson, L.W \& Krathwohl, D.R.

Teknik analisis data yang digunakan yaitu analisis deskriptif dan analisis statistik inferensial. Analisis deskriptif dilakukan untuk mengetahui tinggi rendahnya kualitas dari hasil belajar siswa, baik yang diajar dengan menggunakan model pembelajaran kooperatif tipe make a match berbantuan media PowerPoint, maupun yang menggunakan pembelajaran konvensional. Statistik deskriptif yang digunakan dalam penelitian ini yaitu rata-rata (mean), median, modus, dan standar deviasi. Hasil perhitungan mean, median, modus disajikan dalam bentuk kurva poligon.Analisis statistik inferensial yang digunakan untuk menguji hipotesis yaitu uji-t dengan rumus polled varians. Sebelum menguji hipotesis, maka dilakukan uji prasyarat dengan uji normalitas sebaran daya menggunakan Chi-Square dan uji homogenitas varians dengan menggunakan rumus uji F.

\section{Hasil dan Pembahasan}

Pada data yang dianalisis dalam penelitian ini adalah data hasil belajar IPA siswa yang diperoleh dari hasil post-test yang diberikan pada akhir penelitian pada kelompok eksperimen dan kontrol. Kelompok eksperimen dalam penelitian ini yaitu kelas III B di SD No. 3 Mengwi yang mengikuti model pembelajaran kooperatif tipe make a match berbantuan media PowerPoint. Sedangkan kelompok kontrol dalam penelitian ini yaitu kelas III di SD No. 1 Mengwi yang mengikuti pembelajaran konvensional. Rekapitulasi perhitungan data hasil penelitian tentang hasil belajar IPA siswa dapat dilihat pada Tabel 2. 
Tabel 2. Perbandingan Motivasi Bealajar siswa Pra Siklus, Siklus I dan Siklus II

\begin{tabular}{ccc}
\hline Statistik Deskriptif & Hasil Belajar & \\
& Kelompok Eksperimen & Kelompok Kontrol \\
\hline Mean & 23,45 & 17,45 \\
Median & 24,00 & 17,15 \\
Modus & 24,99 & 17,00 \\
Varians & 13,25 & 18,63 \\
Standar Deviasi & 3,64 & 4,32 \\
Skor Maksimum & 29 & 26 \\
Skor Minimum & 14 & 10 \\
Rentangan & 16 & 17 \\
\hline
\end{tabular}

Berdasarkan Tabel 2, diketahui bahwa rata-rata hasil belajar IPA kelompok eksperimen sebesar 23,45 sedangkan rata-rata hasil belajar IPA kelompok kontrol sebesar 17,45. Hal ini menunjukkan bahwa nilai rata-rata kelompok siswa yang dibelajarkan menggunakan model pembelajaran kooperatif tipe make a match berbantuan media PowerPoint lebih tinggi dibandingkan dengan kelompok siswa yang dibelajarkan dengan pembelajaran biasa (pembelajaran konvensional). Data hasil perhitungan skor hasil belajar IPA siswa kelompok eksperimen kemudian disajikan dalam bentuk kurva poligon seperti pada Gambar 1 berikut.

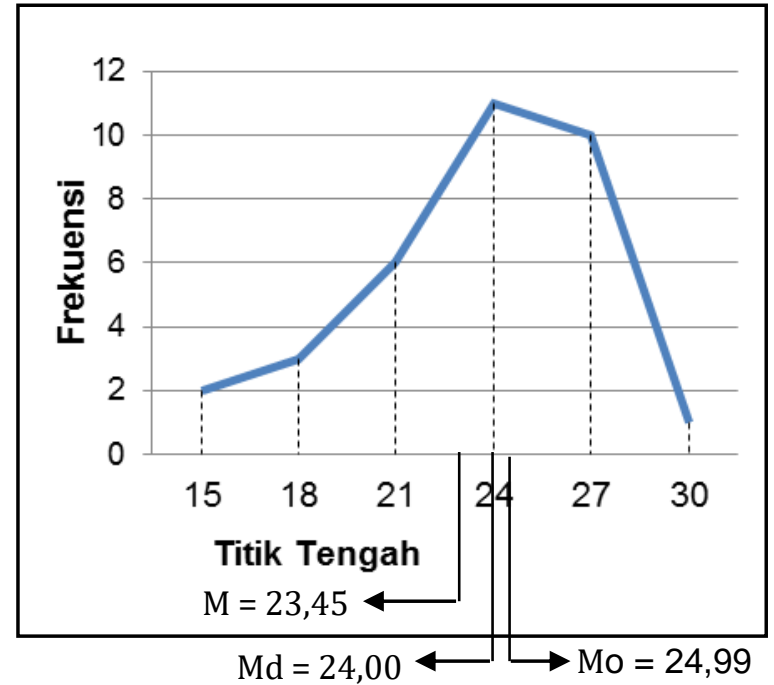

Gambar 1

Kurva Poligon Data Hasil Belajar IPA Kelompok Eksperimen

Berdasarkan kurva poligon pada Gambar 1, tampak bahwa sebaran data kelompok siswa yang mengikuti model pembelajaran make a match berbantuan media PowerPoint menunjukkan Mo $>\mathrm{Md}>\mathrm{M}$ $(24,99>24,00>23,45)$. Hal ini berarti sebagian besar skor siswa kelompok eksperimen cendering tinggi. Sedangkan, data hasil perhitungan skor hasil belajar IPA siswa kelompok kontrol disajikan dalam bentuk kurva poligon seperti pada Gambar 2 berikut.

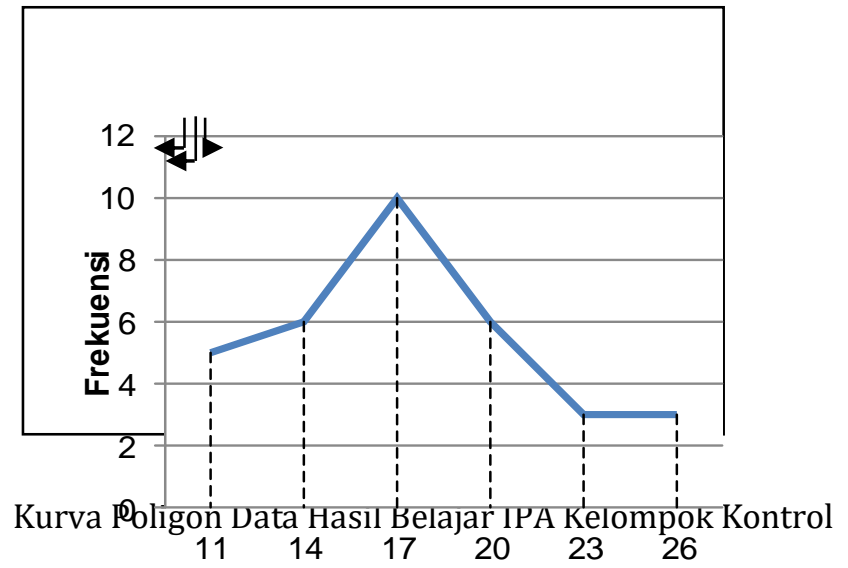

Titik Tengah

Pt. Anggreni Astawa / Pengaruh Model Pembelajaran Kooperatif Tipe Make A Match Berbantuan Media Powerpoint Terhadap Hasil Belajar IPA 
Berdasarkan Gambar 2, tampak bahwa sebaran data kelompok siswa yang mengikuti pembelajaran konvensional menunjukkan $\mathrm{Mo}<\mathrm{Md}<\mathrm{M}(17,00<17,15<17,45)$. Hal ini berarti, sebagian besar skor siswa kelompok konrol cenderung rendah.

Sebelum dilakukan uji hipotesis maka terlebih dahulu dilakukan uji prasyarat statistik yang pertama yaitu uji normalitas. Berdasarkan tabel chi-kuadrat pada taraf signifikansi 5\%, diperoleh $\mathrm{X}^{2}$ tabel sebesar 7,815 dan $\mathrm{X}^{2}$ hitung sebesar 4,839 sehingga dapat diketahui bahwa $\mathrm{X}^{2}$ hitung $<\mathrm{X}^{2}$ tabel $(4,839<$ 7,815). Maka, dapat disimpulkan bahwa data hasil belajar IPA kelompok eksperimen berdistribusi normal. Sedangkan hasil perhitungan uji normalitas kelompok kontrol diperoleh $\mathrm{X}^{2}$ tabel sebesar 7,815 dan $\mathrm{X}^{2}$ hitung sebesar 4,000 sehingga dapat diketahui bahwa $\mathrm{X}^{2}$ hitung $<\mathrm{X}^{2}$ tabel $(4,000<7,815)$. Ini berarti data hasil post-test kedua kelompok berdistribusi normal.

Selanjutnya dilakukan uji prasyarat yang kedua yaitu uji homogenitas varians. Berdasarkan hasil perhitungan menggunakan uji $\mathrm{F}$, diketahui $\mathrm{F}_{\text {hitung }}$ skor hasil belajar IPA siswa kelompok eksperimen dan kontrol adalah 1,41, dan $\mathrm{F}_{\text {tabel }}$ dengan $\mathrm{dk}_{\text {pembilang }}=32$ dan $\mathrm{dk}_{\text {penyebut }}=32$ pada taraf signifikansi $5 \%$ adalah

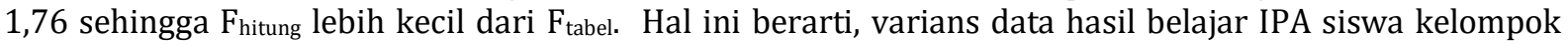
eksperimen dan kontrol adalah homogen.

Setelah melakukan uji prasyarat statistik tersebut, maka selanjutnya dilakukan uji hipotesis dengan uji-t menggunakan rumus polled varians. Berdasarkan hasil perhitungan uji-t, diperoleh thitung sebesar 6,12 . Sedangkan tabel pada taraf signifikansi $5 \%$ dan $d k=(33+33-2)=64$ adalah 2,000. Hal ini berarti $t_{\text {hitung }}$ lebih besar dari $\mathrm{t}_{\text {tabel, }}$ sehingga $\mathrm{H}_{0}$ ditolak dan $\mathrm{H}_{1}$ diterima. Jadi, terdapat perbedaan yang signifikan hasil belajar IPA antara siswa yang mengikuti model pembelajaran kooperatif tipe make a match berbantuan media PowerPoint dan siswa yang mengikuti pembelajaran konvensional pada kelas III SD di Gugus VIII Kecamatan Mengwi tahun pelajaran 2017/2018.

Berdasarkan deskripsi data hasil penelitian, kelompok siswa yang mengikuti pembelajaran dengan model pembelajaran kooperatif tipe make a match berbantuan media PowerPoint memiliki hasil yang lebih tinggi dibandingkan dengan kelompok siswa yang mengikuti pembelajaran konvensional. Tinjauan ini didasarkan pada rata-rata skor dan kecenderungan skor hasil belajar IPA yang diperoleh kedua kelompok. Rata-rata skor hasil belajar IPA siswa kelompok eksperimen adalah 23,45 (kategori sangat tinggi). Sedangkan rata-rata skor hasil belajar IPA siswa kelompok kontrol adalah 17,45 (kategori sedang). Begitu juga yang tampak pada kurva poligon, yang mana sebaran data kelompok menunjukkan Mo $>$ Md > M $(24,99>24,00>23,45)$ yang berarti sebagian besar skor siswa cenderung tinggi. Namun berbeda halnya dengan kelompok kontrol, kurva poligon sebaran data pada kelompok kontrol menunjukkan bahwa Mo $<$ Md < M (17,00 < 17,15 <17,45), yang artinya sebagian besar skor siswa cenderung rendah.

Berdasarkan analisis data menggunakan uji-t, diketahui thitung $=6,12$ dan tabel $(\mathrm{dk}=64$ pada taraf signifikansi 5\%) = 2,000. Hasil perhitungan tersebut menunjukkan bahwa thitung lebih besar dari nilai tabel ( $t_{\text {hitung }}>\mathrm{t}_{\text {tabel), }}$ sehingga $\mathrm{H}_{0}$ ditolak dan $\mathrm{H}_{1}$ diterima. Hal ini berarti, terdapat perbedaan yang signifikan hasil belajar IPA antara siswa yang mengikuti model pembelajaran kooperatif tipe make a match berbantuan media PowerPoint dan siswa yang mengikuti pembelajaran konvensional.

Perbedaan hasil belajar antara kelompok siswa yang mengikuti model pembelajaran kooperatif tipe make a match berbantuan media PowerPoint dan kelompok siswa yang mengikuti pembelajaran konvensional ini disebabkan oleh beberapa hal.

Pertama, adanya unsur kerjasama. Model pembelajaran make a match ini mampu memupuk kerjasama siswa yang terlihat saat siswa bersama kelompoknya menyimak materi pelajaran dan menjawab pertanyaan yang diajukan oleh guru. Selain itu, kerjasama juga terlihat saat siswa bersama kelompok berdiskusi mengenai pasangan kartu soal atau jawaban yang masing-masing anggota kelompok dapatkan. Adanya unsur kerjasama ini menjadikan proses pembelajaran menjadi semakin menarik, siswa menjadi semakin aktif dalam pembelajaran, dan tentunya hal ini meningkatkan proses interaksi siswa. Hal tersebut sesuai dengan pendapat Rusman (2016) yang menyatakan bahwa model pembelajaran make a match ini menuntut aktivitas siswa dalam pembelajaran, yaitu siswa berbuat, berbicara, mendengar, membaca dan bertanya kepada teman kemudian siswa dapat menemukan suatu konsep. Proses pembelajaran seperti ini mencerminkan suatu ciri dari pembelajaran kooperatif mengingat model pembelajaran make a match merupakan salah satu jenis model pembelajaran kooperatif, seperti yang disebutkan oleh Kurniasih \& Sari (2015:56) bahwa, "pembelajaran kooperatif ialah pembelajaran yang menitiberatkan pada gotong royong dan kerja sama kelompok".

Kedua, penggunaan media pembelajaran. Pada pelaksanaan model pembelajaran kooperatif tipe make a match ini, penggunaan media pembelajaran yaitu PowerPoint memiliki peran yang sangat penting. PowerPoint merupakan media pembelajaran yang berbasis multimedia. Mudlofir dan Rusydiyah (2016) mengemukakan bahwa manfaat multimedia dalam pembelajaran, yaitu proses pembelajaran menjadi lebih menarik, lebih interaktif, jumlah waktu mengejar bisa dikurangi, kualitas pembelajaran dapat 
ditingkatkan, dan sikap belajar peserta didik bisa ditingkatkan. Pendapat tersebut sejalan dengan pelaksanaan pembelajaran make a match dengan berbantuan media PowerPoint ini.

Dalam proses pembelajarannya, PowerPoint mampu menumbuhkan ketertarikan siswa pada materi pelajaran yang disajikan. Hal ini dikarenakan PowerPoint mampu memperjelas penyajian informasi sehingga maknanya menjadi lebih jelas. Selain itu, penggunaan PowerPoint juga membuat komunikasi dalam proses pembelajaran menjadi menarik karena PowerPoint dapat mengolah teks, gambar, warna, tampilan, dan animasi-animasi sesuai dengan keinginan dan kreatifitas yang sesuai dengan kebutuhan siswa. Hal tersebut berkaitan dengan pendapat Wirayana (2017)Wirayana (2017) yang menjelaskan bahwa manfaat PowerPoint dalam pembelajaran, yaitu penyampaian materi pelajaran menjadi lebih menarik, menciptakan pembelajaran yang efektif dan efisien, dan materi pelajaran disampaikan secara utuh melalui pointer-pointer materi.

Ketiga, adanya unsur permainan dalam pembelajaran. Shoimin (2014) menyatakan bahwa model pembelajaran make a match ini memiliki hubungan yang erat dengan karakteristik siswa yang gemar bermain. Ini dikarenakan pelaksanaan model make a match ini harus didukung dengan keaktifan siswa untuk mencari pasangan dengan kartu yang sesuai dengan jawaban atau pertanyaan dalam kartu tersebut. Dalam pembelajaran model make a match ini, suasana belajar di kelas diciptakan sebagai suasana permainan, karena adanya kompetisi antar siswa untuk memecahkan masalah terkait dengan materi pelajaran dan adanya penghargaan. Dengan adanya unsur permainan dalam suatu proses pembelajaran, maka pembelajaran menjadi lebih menarik dan menyenangkan. Selain itu, siswa menjadi lebih tertantang untuk belajar dan berusaha menyelesaikan semua permasalahan IPA yang ditemui sehingga pengetahuan yang diperoleh lebih diingat oleh siswa

Ditinjau dari proses pembelajaran, aktivitas siswa yang mengikuti model pembelajaran make a match berbantuan media PowerPoint lebih aktif dalam pembelajaran dibandikan siswa yang mengikuti pembelajaran konvensional. Pada model pembelajaran make a match kegiatan pembelajaran berpusat pada siswa (student centered) dan guru hanya sebagai fasilitator. Siswa terlibat aktif dalam pembelajaran terutama saat melakukan kegiatan make a match (mencari pasangan kartu), siswa terlihat bersemangat saat mencari pasangan kartu yang mereka dapat. Suasana pembelajaran menjadi sangat menyenangkan, dan tidak terlihat siswa yang bosan saat mengikuti pembelajaran. Siswa saling bekerja sama dalam kelompok untuk mencari pasangan kartu dengan tepat. Penggunaan media PowerPoint oleh guru dalam penyampaian materi pelajaran juga menjadikan suasana pembelajaran semakin menarik bagi siswa.

Berbeda halnya dengan pembelajaran konvensional. Dalam proses pembelajarannya guru lebih mendominasi kegiatan pembelajaran sehingga pembelajaran hanya berpusat pada guru (teacher centered). Hal ini berdampak pada kurangnya pengetahuan dan keaktifan siswa saat pembelajaran berlangsung. Interaksi dalam proses pembelajaran hanya berlangsung satu arah yaitu dari guru ke siswa. Guru hanya menerapkan metode ceramah, tanya jawab, dan penugasan. Hal tersebut membuat siswa menjadi pasif karena siswa hanya mendengarkan materi yang disampaikan oleh guru, kemudian mencatat, dan mengerjakan tugas-tugas yang diberikan oleh guru. Pembelajaran yang demikian yang akhirnya menjadikan siswa kurang mendapatkan pengalaman belajar yang optimal dan siswa kurang tertantang atau termotivasi untuk belajar. Selain itu suasana pembelajaran menjadi kurang menarik dan kurang menyenangkan untuk siswa sehingga banyak siswa yang terlihat bosan dan kurang memperhatikan apa yang disampaikan oleh guru. Hal inilah yang mengakibatkan hasil belajar IPA siswa rendah karena proses pembelajaran kurang bermakna bagi siswa.

Perbedaan tahapan pembelajaran dengan model pembelajaran kooperatif tipe make a match berbantuan media PowerPoint pada kelompok eksperimen dan pembelajaran konvensional pada kelompok kontrol tentu memberikan dampak yang berbeda terhadap hasil belajar siswa. Penggunaan model pembelajaran kooperatif tipe make a match berbantuan media PowerPoint mengakibatkan siswa menjadi lebih aktif dalam kegiatan pembelajaran, lebih antusias untuk belajar sehingga mereka mampu memahami materi pelajaran yang disampaikan oleh guru. Dengan demikian, hasil belajar IPA siswa yang mengikuti model pembelajaran kooperatif tipe make a match berbantuan media PowerPoint lebih baik dibandingkan hasil belajar IPA siswa yang mengikuti pembelajaran konvensional(Mudlofir \& Evi F.R, 2016).

Hasil penelitian ini sejalan dengan hasil penelitian tentang model pembelajaran kooperatif tipe make a match yang telah dilaksanakan oleh beberapa peneliti. Seperti penelitian yang dilakukan oleh Tiballa (2017) tentang pengaruh model pembelajaran kooperatif tipe make a match berbantuan peta pikiran terhadap hasil belajar IPA siswa kelas V SD. Penelitian tersebut menunjukkan terdapat perbedaan hasil belajar IPA yang signifikan antara siswa yang mendapat perlakuan model pembelajaran make a match berbantuan peta pikiran dan siswa yang tidak mendapat perlakuan model pembelajaran make a match berbantuan peta pikiran pada siswa kelas V SDN 3 dan 1 Kaliuntu pada tahun ajaran 2016/2017. Hasil belajar IPA siswa yang dibelajarkan dengan model pembelajaran kooperatif tipe make a match 
berbantuan peta pikiran lebih tinggi dibandingkan dengan siswa yang tidak mendapat perlakuan model pembelajaran make a match berbantuan peta pikiran.

Penelitian serupa juga dilakukan oleh Putri (2013) tentang pengaruh model kooperatif tipe make a match berbasis media lingkungan terhadap hasil belajar siswa kelas IV SD dengan hasil penelitian menunjukkan rata-rata kelompok eksperimen lebih besar dibandingkan dengan rata-rata kelompok kontrol. Dalam penelitian tersebut, dibuktikan bahwa terdapat perbedaan yang signifikan hasil belajar IPA antara kelompok siswa yang dibelajarkan melalui model pembelajaran kooperatif tipe make a match berbasis media lingkungan dengan siswa yang dibelajarkan melalui pembelajaran konvensional siswa kelas IV Sekolah Dasar Gugus II Kecamatan Kuta Utara Tahun Pelajaran 2012/2013.

Selanjutnya, penelitian yang dilakukan oleh Dewi (2013) tentang pengaruh model pembelajaran kooperatif tipe make a match berbantuan media grafis terhadap belajar IPS siswa kelas V SDN 18 Pemecutan, yang menunjukkan hasil belajar IPS siswa yang dibelajarkan menggunakan model pembelajaran kooperatif tipe make a match berbantuan media grafis lebih tinggi dibandingkan siswa yang dibelajarkan menggunakan pembelajaran konvensional. Hasil tersebut menunjukkan bahwa terdapat perbedaan yang signifikan hasil belajar IPS antara siswa yang dibelajarkan menggunakan model pembelajaran kooperatif tipe make a match berbantuan media grafis dengan siswa yang dibelajarkan menggunakan pembelajaran konvensional.

Berdasarkan pemaparan di atas, dapat diinterpretasikan bahwa hasil penelitian ini menunjukkan terdapat perbedaan yang signifikan hasil belajar IPA antara siswa yang mengikuti model pembelajaran kooperatif tipe make a match berbantuan media PowerPoint dan siswa yang mengikuti pembelajaran konvensional.

\section{Simpulan dan Saran}

Berdasarkan hasil penelitian dan pembahasan yang telah dipaparkan, maka simpulan penelitian ini yaitu terdapat perbedaan yang signifikan hasil belajar IPA antara siswa yang mengikuti model pembelajaran kooperatif tipe make a match berbantuan media PowerPoint dan siswa yang mengikuti pembelajaran konvensional pada kelas III SD di Gugus VIII Kecamatan Mengwi tahun pelajaran 2017/2018. Sehingga dapat dikatakan bahwa model pembelajaran kooperatif tipe make a match berbantuan media PowerPoint berpengaruh pada hasil belajar IPA siswa pada kelas III SD di Gugus VIII Kecamatan Mengwi tahun pelajaran 2017/2018.

Saran yang dapat disampaikan berdasarkan penelitian yang telah dilakukan ini yaitu sebagai berikut. (1) Siswa diharapkan agar selalu aktif dan bersungguh-sungguh dalam mengikuti pembelajaran sehingga hasil belajar yang maksimal dapat tercapai. (2) Guru diharapkan agar lebih berinovasi dalam pembelajaran dengan menerapkan model pembelajaran kooperatif tipe make a match dengan berbantuan media pembelajaran, untuk meningkatkan hasil belajar siswa dan meningkatkan kemampuan profesional guru dalam mengelola pembelajaran. (3) Kepala sekolah diharapkan dapat mengambil kebijakan untuk menerapkan model pembelajaran kooperatif tipe make a match berbantuan PowerPoint pada mata pelajaran atau tingkatan kelas yang berbeda dan disesuaikan dengan kurikulum yang diterapkan di sekolah. (4) Bagi peneliti lain yang berminat untuk mengadakan penelitian lebih lanjut tentang model pembelajaran kooperatif tipe make a match berbantuan media pembelajaran dalam bidang ilmu IPA maupun ilmu lainnya, agar memperhatikan kondisi siswa, waktu, dan kendala, lainnya yang dialami dalam penelitian ini, sebagai bahan pertimbangan perbaikan dan penyempurnaan penelitian yang akan dilakukan.

\section{Daftar Rujukan}

Agung, A. A. G. (2014). Metodologi Penelitian Pendidikan. Malang: Aditya Media Publish.

Dewi, K. M. (2013). Pengaruh Model Pembelajaran Kooperatif Tipe Make A Match Berbantuan Media Grafis terhadap Hasil Belajar IPS Siswa Kelas V SDN 18 Pemecutan. E-Journal PGSD Pendidikan Ganesha Mimbar PGSD, 1(1).

Giri, I. M. D. R. (2017). Pengaruh Model Pembelajaran TAI Berbantuan Media Power Point Terhadap Hasil Belajar Bahasa Indonesia Siswa Kelas V. E-Journal PGSD Pendidikan Ganesha Mimbar PGSD, 5(2).

Hazillia, D. (2018). Penerapan Model Pembelajaran Kooperatif Tipe Make A Match Berbantuan Kartu Bergambar Untuk Meningkatkan Hasil Belajar Siswa. Jurnal Bidang Pendidikan Dasar (JBPD), 2(1), 70-77.

Kemendikbud. (2003). Undang-Undang Nomor 20 Tahun 2003 tentang Sistem Pendidikan Nasional 
(SISDIKNAS). Jakarta: Kementrian Pendidikan dan Kebudayaan.

Kurniasih, I., \& Sari, B. (2015). Ragam Pengembangan Model Pembelajaran untuk Peningkatan Profesionalisme Guru. Yogyakarta: Kata Pena.

Mudlofir, A., \& Evi F.R. (2016). Desain Pembelajaran Inovatif Dari Teori ke Praktik. Jakarta: PT Raja Grafindo Persada.

Putri, N. M. S. A. (2013). Pengaruh Model Pembelajaran Kooperatif Tipe Make A Match Berbasis Media Lingkungan Terhadap Hasil Belajar IPA Siswa Kelas IV Sekolah Dasar. E-Journal PGSD Pendidikan Ganesha Mimbar PGSD, 1(1).

Rofiana, A. (2017). Implementasi Model Pembelajaran Kooperatif Tipe Make A Match Untuk Meningkatkan Aktivitas Belajar Matematika Siswa (Ptk Siswa Kelas Vii Semester Genap Smp Kasatriyan 1 Surakarta) Tahun 2016/ 2017. Jurnal Fakultas Keguruan Dan Ilmu Pendidikan Universitas Muhammadiyah Surakart.

Rusman. (2016). Model-model Pembelajaran Mengembangkan Profesionalisme Guru. Bandung: PT Mulia Mandiri Press.

Rusman. (2017). Belajar dan Pembelajaran Berorienasi Proses Pendidikan. Jakarta: Kencana.

Shoimin, A. (2014). 68 Model Pembelajaran Inovatif dalam Kurikulum 2013. yogyakarta: Ar-Ruzz Media.

Tangkas, M. (2014). Model Pembelajaran Kooperatif Tipe Make A Match Untuk Meningkatkan Hasil Belajar Kimia Siswa Kelas X Pada Materi Hidrokarbon Sma Negeri 1 Dolo. Jurnal Akademika Kimia, 3(30), 135-142.

Tiballa, M. D. S. (2017). Pengaruh Model Pembelajaran Kooperatif Tipe Make A Match Berbantuan Peta Pikiran Terhadap Hasil Belajar IPA Siswa Kelas V Sekolah Dasar. E-Journal PGSD Pendidikan Ganesha Mimbar PGSD, 5(2).

Utari, U., Degeng, I. N. S., \& Akbar, S. (2016). Pembelajaran tematik berbasis kearifan lokal di sekolah dasar dalam menghadapi Masyarakat Ekonomi Asean (MEA). Jurnal Teori Dan Praksis Pembelajaran IPS, $1(1)$.

Wirayana, I. K. D. Y. A. (2017). Pengaruh Model Pembelajaran Kooperatif Tipe Learning Together (LT) Berbantuan Power Point terhadap Hasil Belajar IPS Kelas V. E-Journal PGSD Pendidikan Ganesha Mimbar PGSD, 5(2). 